\title{
Biomes, ecosystem services and emergy: is there a relationship?
}

\author{
L. Coscieme, N. Marchettini, S. Bastianoni \& F. M. Pulselli \\ Dept. of Chemistry, University of Siena, Italy
}

\begin{abstract}
Ecosystems and human systems are interconnected through a complex series of dynamic relations. In particular, natural functions of ecosystems generate flows of services continuously. To represent adequately the importance of ecosystems for human well-being, the concept of Ecosystem Services (ES) was defined. A complete review of methods and values for the assessment of ES from an economic viewpoint was provided by Costanza et al. in 1997. However, in ES valuation (ESV) several values are neglected or not calculated and estimation methods rely on strictly economic and subjective practices.

In order to have a physical reference upon which an objective (and complementary) evaluation can be based, we used the concept of emergy. Emergy is a thermodynamic entity based on energy quality and hierarchy.

Life on Earth is organized in an ordered series of energy transformations from one type to the next; these types do not have the same ability to do work. Emergy can be defined as the quantity of (solar) energy that is used up directly or indirectly to make a product or a service. An accounting system based on emergy can be implemented to evaluate production processes, ecosystems and nations.

In this paper the emergy of different biomes was calculated and translated into money by means of a specific "environmental" emergy-to-money conversion factor given by the ratio of the renewable emergy supporting the entire biosphere (emergy baseline) to the value of the world ES previously proposed. The results show that the new economic value is higher than classical ESV values.
\end{abstract}

Keywords: ecosystem services, thermodynamic indicators, Emergy evaluation. 


\section{Introduction}

The natural functioning of an ecological system generates an interconnected series of processes that directly or indirectly produce goods (such as food) and services (such as climate regulation or soil formation) for the human society. At the same time these processes sustain the equilibrium of the system itself and the equilibrium of the entire Biosphere [1]. Ecosystem functions regenerate natural capital and produce renewable flows which in part converge in human systems (often after various transformations). In this way, natural originated goods and services are not considered as an integrated part of economic systems, but they are simply utilized $[2,3]$. Because ES are not fully and adequately quantified in terms comparable with economic services and manufactured capital, they are often given too little weight in political decisions [4]. By recognizing ES, and the value provided to humans, ecological economists must develop indicators of value which can be used in decision-making $[3,5]$. An adequate evaluation of ES can guide management policies and sustainable behaviors, for a new harmonization of the anthropic cycles with the natural cycles.

Several works made an estimation of the economic value of ES at various scales $[1,4,6]$. The "classic" approach to ESV is principally based on indirect economic methods, used to internalize the flow of services into Market [7]. The lack of a physical common basis to the ESV techniques cause a huge variability in the results, also for the same service provided by similar ecosystems (i.e. wetlands value in Costanza et al.[4] vs. wetlands value in Schuyt and Brander [6]) $[1,14,15]$. There is a high heterogeneity in the ESV techniques applicable on a territorial system, and the results are principally influenced by the valuation method. The economic evaluation causes also a total disjunction between function and service, which causes a non-effective protection of the ecosystems [8] (for a more complete review of the critics moved to the classic ESV see also Sagoff [16] and Pearce [17] note 1).

To study and evaluate properly the importance of the environment for humans it is necessary to adopt instruments common at both the anthropic and biotic sphere. Relations between man and environment can be represented by flows of matter and energy (withdrawal of resources and discharge of wastes). Accordingly, a thermodynamic-based approach seems to be the more appropriate to understand how to drive the management of natural and anthropic systems toward sustainable dynamics. The powerful use of the economic language can be maintained to dialogue properly with decision makers. However it has to be used only after an evaluation of the ecosystems, based on thermodynamic indicators $[18,19]$.

\section{Methods}

In this paper the emergy evaluation of 16 biomes, as listed in Costanza et al [4], is presented.

Emergy was introduced by H.T. Odum during the $1980 \mathrm{~s}$ as a tool of environmental (but not only environmental) accounting [9-12]. On the basis of a 
thermodynamic hierarchy of energy, starting from solar energy, Odum's research has provided a measure of the environmental work necessary to generate an item or a flow.

Emergy is defined as the quantity of solar energy directly or indirectly necessary to support a given system and its level of organization. The emergy of all inputs to a system is calculated in terms of solar emjoules (sej) by means of suitable conversion factors called transformities (expressed in sej/J), or specific emergy (expressed in sej/g or other units). Emergy represents a measure able to evaluate the convergence of matter and energy (several inputs) to a system on a common basis. In the emergy analysis of all the 16 biomes considered in this paper, only renewable inputs are included, with the exception of some semi-natural or totally anthropic systems, like croplands and urban systems, which exist and provide services to humans using also non renewable inputs like fertilizers and fossil fuels.

Emergy theory offers also important tools that enable a clear communication of the physical evidences of the interactions between environmental and human systems. In particular the Emergy/Money Ratio is able to convert emergy units into "economic terms familiar to most people" (and vice versa).

The Emergy/Money Ratio is usually calculated as the ratio of Total Emergy to the GDP of a nation in a given year and it is used for all the evaluations of territorial subsystems or productive systems within the same nation. In this paper, the concept of "environmental" Emergy/Money Ratio was applied in the evaluation of ecosystem services.

\section{Results and discussion}

A very comprehensive bibliographic research has been necessary to associate an average emergy value to all the 16 biomes (as presented in Costanza et al. [4]). In spite of the high variability found in emergy literature, we think this exercise is important because it represents a rather complete collection of emergy values for different biomes. For some biomes there was an insufficient number of published studies: for them, namely desert and tundra, we have estimated an emergy value using the National Environmental Accounting Database developed by Sweeney et al. [13]. A summary of biomes emergy flows is shown in Table 1.

The highest emergy flows are related to "ecotonal" zones and more heterogeneous biomes. A very high emergy is related to coastal zones due to the high energy of waves and tides. In Emergy literature the role of these inputs in the development of coastal and intertidal ecosystems is currently controversial.

On these energetic inputs, ecosystems base all their internal transformation cycles. The dynamics of these cycles depends on the biota composition and status, and on abiotic configurations and relations with living organisms. On this basis, the system works and produces outputs that could be used directly or indirectly by humans. 
Table 1: $\quad$ Emergy flows of the 16 biomes.

\begin{tabular}{cc}
\hline \multicolumn{2}{c}{ Emergy of different biomes } \\
\hline Biome & $\begin{array}{c}\text { Emergy flow } \\
\text { (sej ha- }^{-1} \mathbf{y r}^{-1} \text { ) }\end{array}$ \\
Open Ocean & $\mathbf{3 . 8 8 E + 1 4}$ \\
Estuaries & $8.84 \mathrm{E}+16$ \\
Seagrass_Algae beds & $1.93 \mathrm{E}+19$ \\
Coral Reefs & $2.94 \mathrm{E}+19$ \\
Shelf & $1.93 \mathrm{E}+19$ \\
Tropical Forest & $4.52 \mathrm{E}+16$ \\
Temperate_Boreal Forest & $1.77 \mathrm{E}+15$ \\
Grass_Rangelands & $7.45 \mathrm{E}+16$ \\
Tidal Marsh_Mangroves & $1.09 \mathrm{E}+16$ \\
Swamps_Floodplains & $3.21 \mathrm{E}+15$ \\
Lakes_Rivers & $4.97 \mathrm{E}+16$ \\
Desert & $1.55 \mathrm{E}+14$ \\
Tundra & $2.01 \mathrm{E}+15$ \\
Ice_Rock & $3.68 \mathrm{E}+15$ \\
Cropland & $2.71 \mathrm{E}+16$ \\
Urban & $1.47 \mathrm{E}+18$ \\
\hline
\end{tabular}

\subsection{An environmental emergy-to-money ratio for evaluating ecosystems and services}

It is possible to define an indicator of the ecosystem conversion of energy inputs into services for humans. To do that, we define a specific "environmental" emergy-to-money ratio given by the sum of independent inputs supporting the entire biosphere cycles (emergy baseline, equal to $15.83 \times 10^{24} \mathrm{sej} / \mathrm{yr}$ [12]) divided by the value of the world ES previously proposed [4] (this value is between a minimum of $18 \times 10^{12} € / \mathrm{yr}$ and a maximum of $62 \times 10^{12} € / \mathrm{yr}$ ). The result is a global range of environmental emergy-to-money conversion factor between $2.57 \times 10^{11} \mathrm{sej} / €$ and $8.68 \times 10^{11} \mathrm{sej} / €$. This ratio represents how much emergy (as a proxy of environmental work) is needed for the global ecosystem to exist and provide ecosystem services (measured in money terms). Using these ratios we can calculate brand new values for the 16 biomes (Table 2), dividing the emergy flow of each biome for the minimum and maximum values of the environmental conversion factor. These values correspond to the amount of emergy necessary to support one unit money of ES that we can expect from a given biome. A range of economic values attached to each biome can be 
Table 2: $\quad$ Classic ESV results and emergy-based values for 16 biomes.

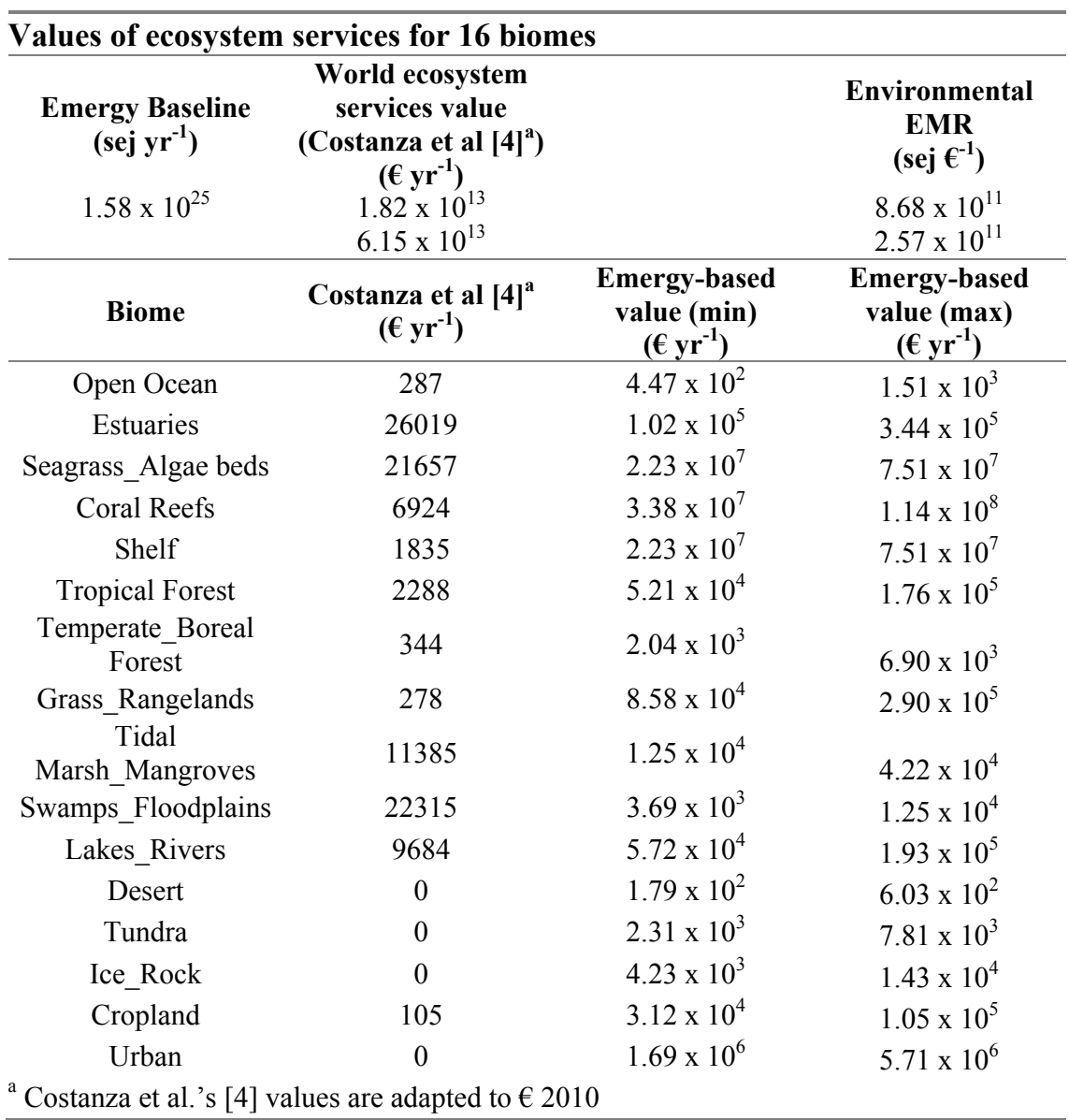

determined. These values are derived from a sort of re-distribution of classic ES values, on the basis of renewable environmental inputs they consume to exist.

\section{Conclusion}

This paper has presented an application of thermodynamic tools (basically using emergy) in ESV. In fact, emergy evaluation can support ESV with a physical basis and contributes to reduce the high heterogeneity of the classic economic evaluation method. A comprehensive bibliographic research, and some original calculations, enabled a first estimation of natural emergy flows to 16 types of ecological system.

The transformation of natural and free inputs (basically sun, rain, geothermal heat, tides and waves) into economically valuable outputs, can be measured by a 
new indicator of the ecosystem work done to provide services to humans. An "environmental" emergy-to-money ratio enabled to estimate a set of new ES values for the 16 biomes. These values are higher than classical ESV values and can be used as a complement of them.

As nations (countries and communities) and economic systems become more and more (apparently) dependent on industrial and technological products, the mayor role of the environment for human well-being becomes less clear to the society [20]. Indicators of the work of the environment for our well-being can help to reform collective ecological knowledge. Maintaining the use of economic language to express the value of ES will permit to define the environmental conservation as a conservation of value, and not as a limit to economic development and to the increase of well-being. Using emergy, and other very informative holistic thermodynamic indicators $[19,21]$, to reach that economically expressed result, will make clear the direct relationship between the value of ES and the work of the biosphere.

\section{References}

[1] de Groot R.S., Wilson M.A., Boumans R.M.J. A typology for the classification, description and valuation of ecosystem functions, goods and services. Ecological Economics, 41, pp. 393-408, 2002.

[2] Daily G.C. (Ed.) Nature Services: Societal Dependence on Natural Ecosystems. Island Press, Washington, D.C., 1997.

[3] Limburg K.E., O’Neill R.V., Costanza R., Farber S. Complex systems and valuation. Ecological Economics, 41, pp. 409-420, 2002.

[4] Costanza R., d'Arge R., de Groot R.S., Farber S., Grasso M., Hannon B., Limburg K.E., Naeem S., O’Neill R.V., Paruelo J., Raskin R.G., Sutton P., van den Belt $M$. The value of the world's ecosystem services and natural capital. Nature, 387, pp. 253-260, 1997.

[5] Millennium Ecosystem Assessment. Millennium Ecosystem assessment. Island Press, Washington, D.C., 2005.

[6] Schuyt K., Brander L. The economic value of the World's wetlands. WWF Living Waters: Conserving the Source of Life. Gland, Switzerland, 2004.

[7] Spangenberg J.H., Settele J. Precisely incorrect? Monetising the value of ecosystem services. Ecological Complexity, 7, pp. 327-337, 2010.

[8] Peterson M.J., Hall D.M., Feldpaush-Parker A.M., Peterson T.R. Obscuring Ecosystem Function with Application of the Ecosystem Services Concept. Conservation Biology, 24, pp. 113-119, 2009.

[9] Odum, H.T. Self organisation, transformity and information. Science, 242, pp. 1132-1139, 1988.

[10] Odum, H.T. Environmental Accounting. Emergy and Environmental Decision Making. John Wiley and Sons. New York, 1996.

[11] Odum H.T., Brown M.T., Brandt-Williams S. Introduction and Global Budget, Folio \#1. Handbook of Emergy Evaluation. Center for Environmental Policy, University of Florida, Gainesville, USA, 2000. 
[12] Odum H.T. Emergy of Global Processes, Folio \#2. Handbook of Emergy Evaluation. Center for Environmental Policy, University of Florida, Gainesville, USA, 2000.

[13] Sweeney S., Cohen M.J., King D., Brown M.T. Creation of a global emergy database for standardized national emergy synthesis. In Emergy Synthesis 4: Theory and application of emergy methodology (Brown M. ed.), Gainesville, FL, pp. 23.1-23.15, 2007.

[14] Wilson M.A., Carpenter S.R. Economic valuation of freshwater ecosystem services in the United States 1971-1997. Ecological Applications, 9, pp. 772-783, 1999.

[15] Turner M.G., Odum E.P., Costanza R., Springer T.M. Market and Nonmarket Values of the Georgia Landscape. Environmental Management, 12, pp. 209-217, 1988.

[16] Sagoff M. Can We Put a Price on Nature's Services? Report from the Institute for Philosophy and Public Policy, Vol. 17, 1997.

[17] Pearce D. Auditing the Earth: The Value of the World's Ecosystem Services and Natural Capital. Environment, 40, pp. 23-28, 1998.

[18] Odum H.T., Odum E.P. The Energetic Basis for Valuation of Ecosystem Services. Ecosystems, 3, pp. 21-23, 2000.

[19] Jorgensen S.E. Ecosystem services, sustainability and thermodynamic indicators. Ecological Complexity, 7, pp. 311-313, 2010.

[20] Pilgrim S.E., Cullen L.C., Smith D.J., Pretty J. Ecological Knowledge is Lost in Wealthier Communities and Countries. Environmental Science \& Technology, Vol. 42, pp. 1004-1009, 2008.

[21] Tilley D.R. Emergy Basis for Forest Systems. University of Florida, 1999. 